\title{
CCL14 Gene
}

National Cancer Institute

\section{Source}

National Cancer Institute. CCL14 Gene. NCI Thesaurus. Code C24769.

This gene is involved in the regulation of cellular calcium levels and in the proliferation of monocytes. 